\title{
Fraud prevention of village funds in East Java Indonesia
}

\author{
Abdul Hamid ${ }^{\mathrm{a}, \mathrm{b}^{*}}$ and Mohammad Nasih
}

${ }^{a}$ Doctoral Student of Accounting Study Program, Postgraduate School, FEB Universitas Airlangga, Surabaya, Indonesia

${ }^{b}$ Lecturer at Sekolah Tinggi Ilmu Ekonomi Mahardhika, Surabaya, Indonesia

${ }^{c}$ Universitas Airlangga, Surabaya, Indonesia

\section{H R O N I C L E}

\begin{tabular}{l} 
Article history: \\
Received: December 14, 2020 \\
Received in revised format: \\
January 292021 \\
Accepted: March 9, 2021 \\
Available online: \\
March 9, 2021 \\
\hline Keywords: \\
Anti-Fraud Tactics \\
Fraud \\
Village \\
funds
\end{tabular}

\section{Introduction}

Fraud acts occur because opportunities arise from weaknesses in the system so that they are exploited by individuals (Wolfe \& Hermanson, 2004, p. 39). That is, an effective system makes it difficult for individuals to do evil. Fraud is prejudiced to be an important issue which is a problem and is dealt with in-depth throughout the group of institutions and businesses (Perri \& Brody, 2012). For institutions to survive, they must detect these problems and overcome them wisely (Button et al., 2012). The motive of cheating leads to any activities planned that are carried out by a person or a community of people to deceive the other party (Halbouni et al., 2016). From the twenty- first decade, the company had a strong, monumental, and stable collapse because of fraud (Kummer et al., 2015). The presence of cases of fraud that spread widely in all parts of society already makes the behavior of evil as an evil primary business today (Kapardis \& Papastergiou, 2016; Wells, 2004). Air landing Association of Fraud Examiner (ACFE), a general agency, collapsed around 5 percent of the acquisition of profit per period. The fraud case does not merely make the company collapse, but it also leads to marginal business. Based on ACFE (2012) and RATLEY (n.d.) Most of the impact of losses arising from marginal businesses is estimated at \$147,000, in addition to the loss mostly on strong institutions is $\$ 100,000$. However, if preventive measures are not taken to prevent fraud, the

* Corresponding author.

E-mail address: abdul.hamid-2019@, feb.unair.ac.id (A. Hamid)

(C) 2021 by the authors; licensee Growing Science, Canada doi: $10.5267 /$ j.msl.2021.3.006 
business may not succeed. Finally, when fraud becomes a cost of operation, it will put the organization at a competitive disadvantage (Adams et al., 2006).

\section{Preliminary}

Motif fraud refers to the act of the activities planned and in doing by someone or community person with a desire to cheat the group of others (Halbouni et al., 2016). Cases of fraud are widespread throughout the world and have made fraudulent behavior as a crime primary business today (Kapardis \& Papastergiou, 2016; Wells, 2004). Based on the Association of Fraud Examiners (ACFE), a general agency has collapsed about 5 percent of the acquisition of the profits per period. From the most important principles of this section, it seems insignificant; however, using this share of suffering throughout the United States, estimates of losses exceed \$ 3.5 trillion (ACFE, 2012). In Indonesia, Village funds oriented to the reduction of the level of poverty of the population through reduction ration portions are divided thoroughly and increase the allocation formula, the provision of value that is greater to jump was poor and affirmation for disadvantaged areas and very behind with the number of residents of the poor was great. Villages to fully establish anti-fraud tactics resulting from studies that were mainly conducted on village fund management, such as data from ICW from 2015 to 2017 there were 112 cases of fraud committed by the Village Head, namely in 2015 there were 15 cases, in 2016 there were 32 cases and in 2017 there were 65 cases. From this cause and effect, it is relevant to hold more and more studies that focus primarily on preventive fraud measures in the management of village funds and this research is one of the efforts towards preventing the fraud of village funds. The basic theory of this study is the diamond fraud theory. In 2004 a theory of fraud emerged, proposed by Wolfe and Hermanson, a theory they discovered is called the Fraud Diamond Theory. Diamond fraud theory is the perfection of fraud triangle theory. Diamond fraud theory capability of adding elements/capabilities (capability) as the fourth element in addition to the element of pressure (pressure), opportunity (opportunity), and rationalization that have previously been described in the theory of fraud triangle. According to Wolfe and Hermanson, no deception or fraud may occur without a person who has a capable skill to practice fraud or cheating them. Another objective of this research paper is to examine dependency studies that have previously ignored the problem of village fund fraud and aim to assess the extent of fraud prevention tactics in a non-western context such as Indonesia. Besides, this review suggests tactics against effective fraud at the smallest institutions such as villages and village heads as the person in charge of village funds. The novelty of this study is that linking the theory of diamond fraud has been widely studied, but the results are reported differently. From the review earlier that in discussing ad custom experience honesty internal control and proper supervision. This study adds to the development of religious attitudes and behavior in terms of personal uniqueness. The effectiveness of the internal control system in the research of (Barra, 2010) and (Doig, 2014) has a positive effect on the tendency of fraud, in the research of Donelson et al. (2017), Berger et al. (2017) and Mihret (2014), which has a negative effect, whereas in (Hollow, 2014). Actions of religion are a close correlation to the principle of a person in the belief that can be connoted with the principles of belief, behavior, religion, and religiosity attitude. The behavior of religious people is to know and want to personally accept and approve religious images that exist and become their own, then the beliefs and faith that have been inherent in themselves manifested in everyday behavior. This event is in line with a review of (Conroy \& Emerson, 2004) rule that people who are committed to their religion can make decisions according to their moral beliefs.

The final part of this paper is then arranged into several steps. while the second step, in the previous paper, discussed the deterrence and discovery of phishing observed, along with illustrations of phishing systems. In the third step, the study procedures are investigated. then the fourth step, the results of the assessment are presented, and in the final step an overview and recommendation are made.

\section{Assessment Motives}

According to Shanmugam et al. (2012), each small institution is more often affected by fraudulent activities by its employees and less able to bear the negative consequences compared to giant institutions. although this problem occurs in village-level institutions in Indonesia, there is a dearth of empirical studies that address this issue and its impact on the performance and productivity of this organization. Therefore, conducting this research is very appropriate and is primarily expected to be able to enhance and enrich the inherent references to deception and preventive measures from perceptions of new habits from village heads and village secretaries and heads of finance through religious attitudes.Pragmatically, finding this research will be relevant for actual villages who want to improve the welfare of village communities. Henceforth, this research is aimed at looking at economic and efficient fraud prevention tactics that can be quickly applied by the Village Head in Indonesia. So, this can encourage village funds to be less exposed to criminal activities.

Attract more of the study is to look at the perceptions, views, knowledge, and techniques from the village heads, secretary of village heads, and financial treasurers as an element of decision highest institution village level on fraud prevention mechanism village fund management in existence and effectiveness. 


\section{Village funds as a research context}

As Law No. 6 of 2014 article 72 paragraph (2), the portion of the Village Fund derived from the state budget is central government spending by effecting an agenda that is based on a thorough village and justice. The APBN is the cost of the Village Fund, whose role is to finance the continuity of government, a manifestation of development, social renewal, and the strength of the population in the village. The cost of Village Funds sourced from the APBN is allocated as much as 10 percent of and outside funds Transfer to the Regions (on top) in waves. Cost of Village is calculated based on the number of villages and allocated wit pay attention to many residents, score distress cost of living, area, and the difficulty level of geography to improve the welfare and equitable development of the village. Next, to respond to the Village Fund amounting to 10 percent of transfers to areas, the Government has formulated a road map of the Village Fund 2015 allocation for 2019 referring to Regulation No. 22 The year 2015 on the Amendment of the PP 60 of 2014 concerning Village Funds Sourced from the State Budget. Based on the road map, the Government is committed to allocating costs and the village will increase in waves to 10 percent of transfers to the regions in 2017. Regulation of the Minister of Rural, Regional Development of Disadvantaged, and the Transmigration Republic of Indonesia Number 16 the Year 2018 on prioritizing the utilization of funds in December a year in 2019 this is a reference to the main for the village in entire Indonesia in organizing Authority of resources and authority of the territorial Scale Village which financed funds village in the year 2019.

\section{Literature review and hypothesis development}

\subsection{Fraud prevention measures}

Based on Adams et al. (2006), prevention is the most economical way to overcome financial deficits due to fraud. Fraud prevention forms on some serious tactics initiated by institutions to prevent or withstand fraud. Some previous studies have found that many companies focus more on commitment than deterrence and tend to arrange individual events (Bishop, 2004; Omar \& Abu Bakar, 2012; KPMG, 2013). In addition, Laufer (2011) argues that counterfeiting is more economical than finding fraud. His findings further explained that it was stated that the difference between fraud and detection would lead to fraud in the target villages. Findings explain further stated that the differences that exist between the occurrence and detection of fraud will lead to the village becoming victim of fraud. The potential loss of funds incurred includes expenses from legal risk, negative coverage for institutions, and low creativity and character. Whereas the object of fraud may be subject to all supplementary burdens, it is not certain that the victim will return the lost or deceived funds.

Several methods of counterfeiting are used by institutions and companies to reduce the impact of fraud in their institutions and companies. Efforts are done including internal controls, procedures of recruitment of employees strictly, training and education of staff about fraud prevention, equipping employees with the reporting system of the prevention of fraud, etc. (Bierstaker et al., 2006; Daigle et al., 2014; Laufer, 2011; Shanmugam et al., 2012). Air landmark of planning and Control Anti-fraud management issued by the American Institute of Public Certified Accountants ((AICPA), 2002), the prevention of fraud, so prevention and tactics to avoid fraud made three sets of actions and in previous studies, and this study adds another set of actions based on the study of (Neff, 2006) so that they become four sets of actions as follows:

1) Developing and preserving honesty.

2) Measuring the effect of fraud and men run the techniques and methods for mitigating identified risks.

3) Developing an appropriate monitoring system.

4) Cultivating religious attitudes and behavior in everyone.

\subsection{Develop and preserve individual honesty habits}

Developing and preserving the habit of honesty holds a task central to the survival of the organization. (Pong et al., 2009) found only company premises with polite behavior that would be able to survive in a period of conservative and holding stakeholders. Conversely, the failure of top management to promote high values of honesty tends to cause employees to commit fraud (Murphy \& Dacin, 2011). By establishing the habit of honesty, management can identify actions respectful to received and discuss on all employees (Sengur, 2012). Previous studies have found that if an honest habit is built up to be decisive in counteracting corporate fraud cases (AICPA, 2002; IUCN, 2008; Pong et al., 2009; CIMA, 2009; Murphy \& Dacin, 2011; Sengur, 2012).

According to the discussion above, it may be his understanding that if the head of the village to build the habit of honesty among employees will influence the attitudes and behavior of them positively, leading to the deterrence scams powerful. Based on this understanding, the next hypothesis is made as follows:

$\mathrm{H}_{1}$. There is a positive correlation between the habit of honesty and effective fraud prevention mechanism of village funds in Indonesia. 


\subsection{Assess the internal control process}

For fraudsters to carry out their actions must be perceived opportunities, such as weak internal control, which allows them to commit unrestrained fraud (Girgenti \& Hedley, 2011). As well, Laufer (2011) and Wells (2004) argue that the institutions were small and increasingly sensitive to deception because they find the tactics of anti-fraud less widely practiced when compared with the institution's great. According to Laufer (2011), the examination consists of: the order of the institution checks and balances are prepared to establish reportage financially credible, work processes on effectively and efficiently, protect assets against wiping and the use of unauthorized and discipline to the rules and regulations in force.

Ashbaugh-Skaife et al. (2008) formulated that the internal controls were effective as a tool to measure the performance including the village fund manager. control effective internal leads to the internal data more reliably, such as inventory, accounts payable, and performance measures. As a result, this method contributes to the determination of better internal steps, better operations, and deception by lower employees. Also, strong internal controls strengthen corporate governance, enabling management to achieve its goals and minimize the threat of fraud by giving staff the skills and means to understand and detect fraud (Peterson \& Zikmund, 2004), (Shanmugam et al., 2012) argue that apart from the size of the institution and type of business, it is very important for good internal control to prevent fraud, detect fraud and produce appropriate financial information. Conversely, weak or non-existent internal controls are considered among the main factors that trigger fraud in village funds (Laufer, 2011; Wells, 2004). Based on the discussion, some facts show the village chief to implement supervision effective internal; more likely to produce effective fraud prevention mechanisms. Based on this understanding, the following hypotheses are developed:

$\mathrm{H}_{2}$. There is a positive correlation between internal controls and effective fraud prevention mechanisms from village funds in Indonesia.

\subsection{Make the right monitoring process}

Literature beforehand found deterrence system Fraud effective supervision requires a good role ((AICPA), 2002), (IUCN, 2008). Besides, (Deng et al., 2015) found that the lack of a supervisory function increases the chances of fraud. The application of the system of supervisory roles depends on the size of the institution. In village institutions, where the village head is often the leader of the highest institution in the village, the position is right to establish the habit of honesty and high integrity and control the activities of their institution. Although the village head has full responsibility for fraud prevention in the village, they can appoint someone or unit to be responsible for the institution's risk management process. Besides, to make prevention mechanisms more efficient, management must consider including third parties, such as external auditors or forensic accountants, often to verify the accuracy of transactions and accounts (Seetharaman et al., 2004). Likewise, (Carpenter \& Mahoney, 2001) argue that internal auditors, who understand the types of fraud schemes that threaten their institutions and the extent of their occurrence, will be more likely to be prepared to deal with such fraud, and he or she will recognize the corresponding red flag.

Sourced in the above discussion, the research paper gives an understanding that when the village chief develops a thorough oversight role, it can direct the deterrence mechanism fraud effectively. Based on this understanding, the following hypotheses are developed:

$\mathrm{H}_{3}$. There is a correlation to acquisitiveness between the development role of careful monitoring and effective fraud prevention mechanism of village funds in Indonesia.

\subsection{Building religious attitudes in individual activities}

Religious beliefs according to Durkheim in (Glock \& Stark, 1970) are formulated as: the order of beliefs and practices attached to a sacred state, that is, something separated and beliefs and illegitimate practices attached to an exclusive group of disciplines called Church, many people obey them. In other terms, religious belief is a mirror of the person which is shown in all parts of life based on what is imagined, impregnated, and believed to be the direction of the belief held (Glock \& Stark, 1970). Religious affairs cannot occur when the person performs acts of worship, but also when undergoing other routine activities caused by the desire of the level of confidence of that person. Religious belief is not only all activities that can be seen but also activities that are not seen. Sourced in the research paper (Glock \& Stark, 1970) there are five levels of religious belief, namely:

1) The ideological level believes that all beliefs have a doctrine or basis of belief held by elected adherents.

2) Ritual level sticks apply how strong the belief, loyalty, and obedience of the person to the flow that is believed in a particular religion. 
3) Experiential levels are very close to one's feelings for supernatural powers.

4) Intellectual Level has the hope to see how much knowledge and understanding someone has about the flow or teachings and habits of rules in their own beliefs.

5) Depth consequence leads to any improvement in behavior of the person and their business applying his belief inside the way of life every day.

Sourced in the discussion above, this study assumes that when the village chief develops attitudes and religious behavior in individuals, it can be demanding on deception deterrence mechanisms effectively. Based on this thinking, the following hypotheses were developed:

H4. There is a positive correlation around the attitude of religious beliefs of people and the procedures for preventing effective fraud from village funds in Indonesia.

\section{Methodology}

Analysis This study uses quantitative methods to achieve research objectives. Data were collected through a questionnaire survey with the design adopted from previous studies. The study community consists of the village head and village secretary and village finance treasurer because they are decision-making officials in the village administration and are considered competent to provide the right information used in this study.

The questionnaire consisted of four sections (Appendix): the main part related to the informant demographic profile; the second part asks the informant about the level of implementation of the fraud prevention measures in their institutions; The third section asks the informant about their perception of the effectiveness of the tactics that exist in the way of warding off deception in the institution of them, and the last part relates to the effectiveness of overall fraud prevention measures. Informants were asked to indicate their level of compatibility at each statement by applying a four-point Likert measure.

All recommended informants must have three observations for each item (Hair Jr et al., 2016). Based on this procedure, the minimum total number of informants in this study was 87 (29X3). There are three stages in data collection. In the first stage, the researchers sent official letters to these institutions to inform them that they were chosen as informants and to ask their permission to participate in this research. In the next stage, the researcher visits targeted village institutions to explain the purpose of this study and convince them to take an active role. In the end, 425 questionnaires prepared in every institution village, but the results confirm only 250 villages were ready to provide information related to this study. Furthermore, and 250 questionnaires were distributed to each village, there are 71 questionnaires issued for not meeting the criteria for data processing or invalid so that only 179 can be used.

\section{Data Analysis}

\subsection{Demographic characteristics of respondents}

\section{Community and Samples}

The community of research this is the unit of government the smallest are villages that exist in the province in Java East based on the statistical data in 2018 amounted East Java 8496 villages. The reason why researchers make Java East as an object of study is because Java East is ranked the second number of villages most in Indonesia after the Javanese middle rank first and area privileges Aceh ranking third. Samples of research this is the head of the village, the secretary of the village, treasurer part of finance. The number of samples was taken from the population of researchers using the formula Slovin who raised (Umar, 2013, p. 78) with a level of confidence of $95 \%$ with a value of e $=5 \%$ or the rate of error of 0.05 . is as follows, namely:

$$
n=\frac{N}{1+N e^{2}}
$$

where:

$n=$ representative value

$N=$ Community size

$e=$ for the error 
Applying Eq. (1) yields,

$$
n=\frac{8.496}{1+8.496(0,05)^{2}}=424,8 \approx 425 \text {. }
$$

\section{Characteristics demographic informant}

The informants in this review consisted of the Village Head (24.02 percent), the Secretariat of the village (47.49 percent), treasurer of financial (12.85 percent), and the rest of his other job positions as head of service (15.64 percent). In total, (81.56) percent of informants were men, and (18.44) percent were women. In terms of education, (64.80) percent of them completed high school, (22.91) percent of them had graduate degrees, (8.94) percent of informants had master's degrees, (1.12) percent had Ph.D. degrees, (8.80) percent hold a diploma and the rest have other educational backgrounds. About work experience, (25.70) percent of participants had less than 5 five years of work experience, (65.36) percent had 5 to 10 years of work experience, and (8.94) percent had work experience above 10 years. In terms of the scope of the amount of APBDes, (24,028) percent of participants came from the APBDes the range reached IDR 1,000,000,000 (75.42) percent IDR 1,000,000,000 to IDR 2,000,000,000 and (0,56) percent of the APBDes above IDR 3,000,000,000.

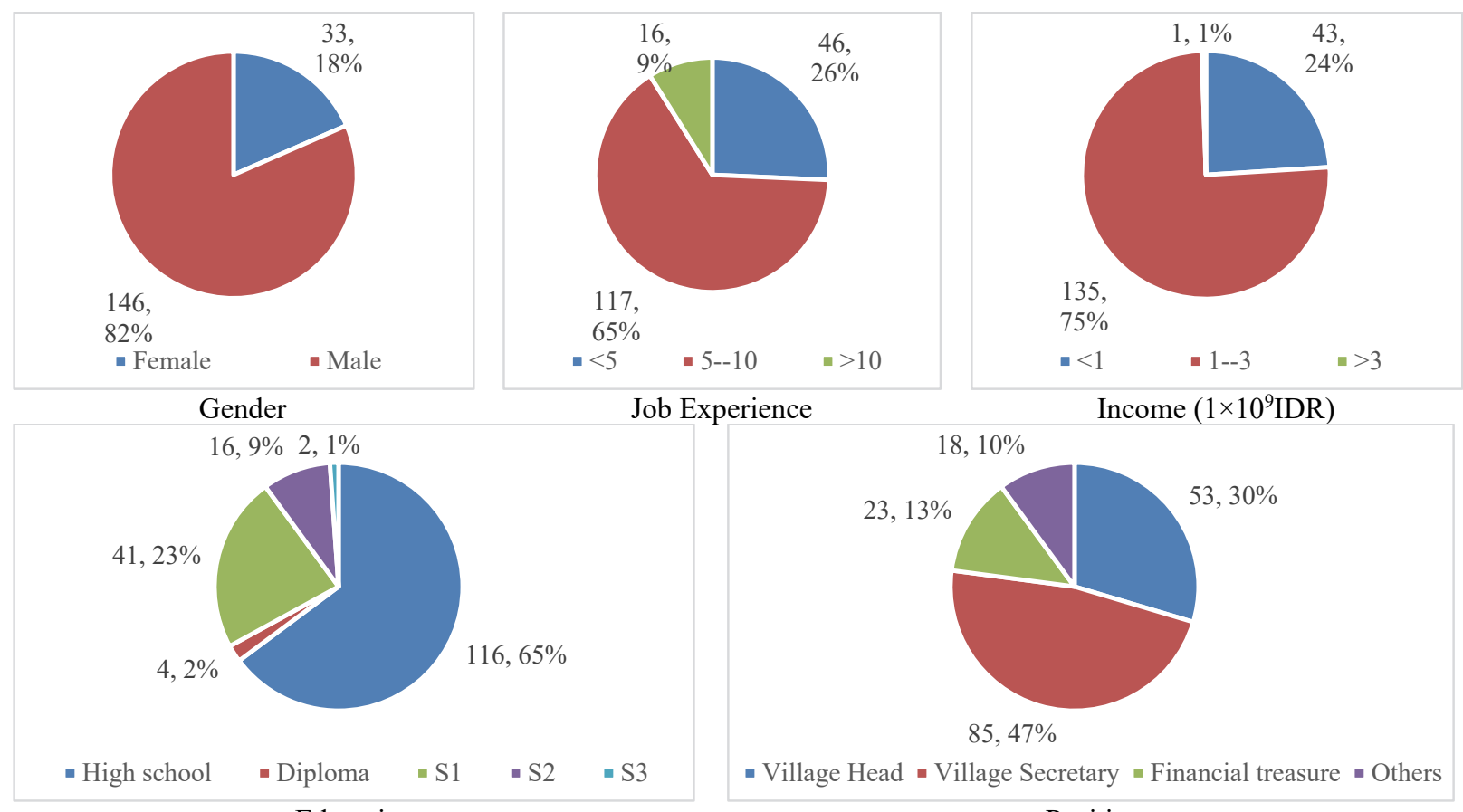

Education

Fig. 1. Personal characteristics of the participants

\subsection{The existence of tactics to prevent fraud management of village funds in Indonesia.}

Based on previous research, informants were given 33 fraud prevention measures and were asked to assess the level of the existence of these tactics in their institutions. Cheating prevention tactics are scored from not being used at all (1) to frequently used (4). Such as that shown in Table 1, Establish a positive working environment (3.83), I believe that God will protect me (3.81) and Establish a code of conduct or ethics policy for rural organization (3.67) classified as deterrence measures exist deception contained in the management of funds village in Indonesia. Instead, how much do you think you are a spiritual person (2.82), In your religious or spiritual tradition, how often do you meditate (2.91) and Public religious beliefs How often do you participate in religious ceremonies $(3,01)$ is classified as the most common abusive tactics. It is also astonishing to note that from these 33 methods of deterrence of fraud, it only builds a positive work environment and I believe in God who always watches over me who gets the highest score and is the threshold of existence.

The results of this study are supported by (Laufer, 2011) who argues that due to lack of resources in the village, a small institution has implemented fewer fraud prevention tactics or anti-fraud controls that are more ineffective compared to large institutions. Impact, institutions are small like the village becomes more vulnerable to fraud. In another study, revealed in its 2012 study that there were large differences in the application of fraud prevention tactics between large and small institutions. In general, the villages do not have an anonymous fraud information system, do not have a code of ethics, do not conduct fraud awareness training, and have weak internal controls (ACFE, 2012) and do not provide a high portion of religious behavior in their institutionalized activities. 
Table 1

The result of weighting fraud prevention tactics and the level of effectiveness of fraud prevention tactics

\begin{tabular}{|c|c|c|c|c|c|c|}
\hline No & Indicators & $\mathbf{N}$ & The Mean & 密 & 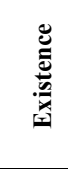 & 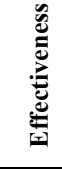 \\
\hline 1 & Establish high morality or lead by example & 179 & 3.71 & 0.48 & 3.71 & 3.66 \\
\hline 2 & Establish a code of conduct or ethics policy for rural organizations & 179 & 3.67 & 0.53 & 3.67 & 3.61 \\
\hline 3 & Establish a positive working environment & 179 & 3.83 & 0.38 & 3.83 & 3.77 \\
\hline 4 & Take firm and consistent actions to respond to reported fraud cases & 179 & 3.74 & 0.44 & 3.74 & 3.67 \\
\hline 5 & Conduct fraud awareness training & 179 & 3.55 & 0.61 & 3.55 & 3.50 \\
\hline 6 & Conduct employee background checks before recruiting. & 179 & 3.60 & 0.54 & 3.60 & 3.60 \\
\hline 7 & Identify and measure fraud risks or conduct fraud risk assessments & 179 & 3.43 & 0.61 & 3.43 & 3.47 \\
\hline 8 & $\begin{array}{l}\text { Implement and monitor appropriate preventive measures and internal investiga- } \\
\text { tion controls }\end{array}$ & 179 & 3.48 & 0.55 & 3.48 & 3.47 \\
\hline 9 & $\begin{array}{l}\text { Change the activities and procedures of village organizations to reduce or elim- } \\
\text { inate the risk of fraud or enforcement of laws and regulations }\end{array}$ & 179 & 3.55 & 0.54 & 3.55 & 3.49 \\
\hline 10 & Raise management's attention to fraud risks & 179 & 3.55 & 0.56 & 3.55 & 3.54 \\
\hline 11 & Designate a specific person or department to manage preventive measures and & 179 & 3.35 & 0.72 & 3.35 & 3.28 \\
\hline 12 & $\begin{array}{l}\text { Encourage employees to sincerely report relevant evidence provided by col- } \\
\text { leagues regarding suspicious or observed fraud cases }\end{array}$ & 179 & 3.51 & 0.57 & 3.51 & 3.47 \\
\hline 13 & $\begin{array}{l}\text { Let third parties (such as external auditors, registered fraud inspectors) partici- } \\
\text { pate in transaction verification and village financial reporting accounts. }\end{array}$ & 179 & 3.40 & 0.67 & 3.40 & 3.32 \\
\hline 14 & I believe that God will protect me & 179 & 3.81 & 0.39 & 3.81 & 3.83 \\
\hline 15 & $\begin{array}{l}\text { I have a profound responsibility for reducing the pain and suffering in the } \\
\text { world }\end{array}$ & 179 & 3.45 & 0.58 & 3.45 & 3.51 \\
\hline 16 & I strive to bring religious beliefs into all other affairs of life & 179 & 3.59 & 0.58 & 3.59 & 3.59 \\
\hline 17 & I want to be close to or one with God & 179 & 3.69 & 0.46 & 3.69 & 3.64 \\
\hline 18 & I feel God's love directly or through others & 179 & 3.55 & 0.54 & 3.55 & 3.55 \\
\hline 19 & The beauty of creation touched me spiritually & 179 & 3.56 & 0.61 & 3.56 & 3.52 \\
\hline 20 & I feel the presence of God & 179 & 3.68 & 0.49 & 3.68 & 3.64 \\
\hline 21 & I find strength and comfort in religion & 179 & 3.70 & 0.46 & 3.70 & 3.67 \\
\hline 22 & I feel peace or harmony in my heart & 179 & 3.44 & 0.55 & 3.44 & 3.45 \\
\hline 23 & I forgave myself for what I did wrong & 179 & 3.21 & 0.74 & 3.21 & 3.19 \\
\hline 24 & I forgive those who hurt me & 179 & 3.44 & 0.63 & 3.44 & 3.46 \\
\hline 25 & I know God forgive me & 179 & 3.37 & 0.63 & 3.37 & 3.37 \\
\hline 26 & I have considered how my life can be part of a greater spiritual force & 179 & 3.32 & 0.66 & 3.32 & 3.31 \\
\hline 27 & I work with God & 179 & 3.09 & 0.83 & 3.09 & 3.13 \\
\hline 28 & I seek strength, support and guidance from God & 179 & 3.59 & 0.52 & 3.59 & 3.56 \\
\hline 29 & Except for mosques, churches or other places of worship, how often do you & 179 & 3.30 & 0.55 & 3.30 & 3.28 \\
\hline 30 & In your religious or spiritual tradition, how often do you meditate & 179 & 2.91 & 0.66 & 2.91 & 2.92 \\
\hline 31 & Public religious beliefs How often do you participate in religious ceremonies & 179 & 3.01 & 0.61 & 3.01 & 3.02 \\
\hline 32 & $\begin{array}{l}\text { Religious beliefs with your own values the degree to which you consider your- } \\
\text { self to be a religious believer }\end{array}$ & 179 & 3.02 & 0.56 & 3.02 & 2.99 \\
\hline 33 & How much do you think you are a spiritual person & 179 & 2.82 & 0.69 & 2.82 & 2.85 \\
\hline
\end{tabular}

(Sow et al., 2018; Neff, 2006)

\subsection{The effectiveness of the tactics p Flood protection institution fraud in a small one in Indonesia}

These tactics are ranked from very ineffective (1) to very effective (4). Analytical results show that the informants felt that some actions were more effective than others. Indeed, of the 33 measures of prevention of fraud, I believe that God will protect me $(3,81)$, I have considered how my life can be part of a greater spiritual force $(3,32)$, I find strength and comfort in religion $(3,70)$, Take firm and consistent actions to respond to reported fraud cases $(3,74)$ and Establish high morality or lead by example (3.71) are the most effective fraud prevention practices felt in managing village funds in Indonesia, because they receive the highest average scores. Instead, how much do you think you are a spiritual person (2.82), In your religious or spiritual tradition, how often do you meditate (2.91), and religious beliefs with your own values the degree to which you consider yourself to be a religious believer $(3,02)$, received the lowest effectiveness rating. Table 1 presents the level tactic's effectiveness of fraud prevention was registered. Good religious behavior such as I believe in God who watches over me and builds a positive work environment in counteracting fraud scandals that are reported to receive a high degree of existence and perceived effectiveness if done consistently. Conversely, doing in your religious or spiritual tradition, how often do you meditate and Religiosity with your values to what extent do you consider yourself a religious person to have a low level of existence; however, they receive a high level of effectiveness. This shows that village fund managers who have religious behavior can be a preventive force to protect themselves from fraudulent activities. Fig. 2 presents a comparative analysis of the existence and effectiveness of village fund fraud prevention mechanisms in Indonesia. 


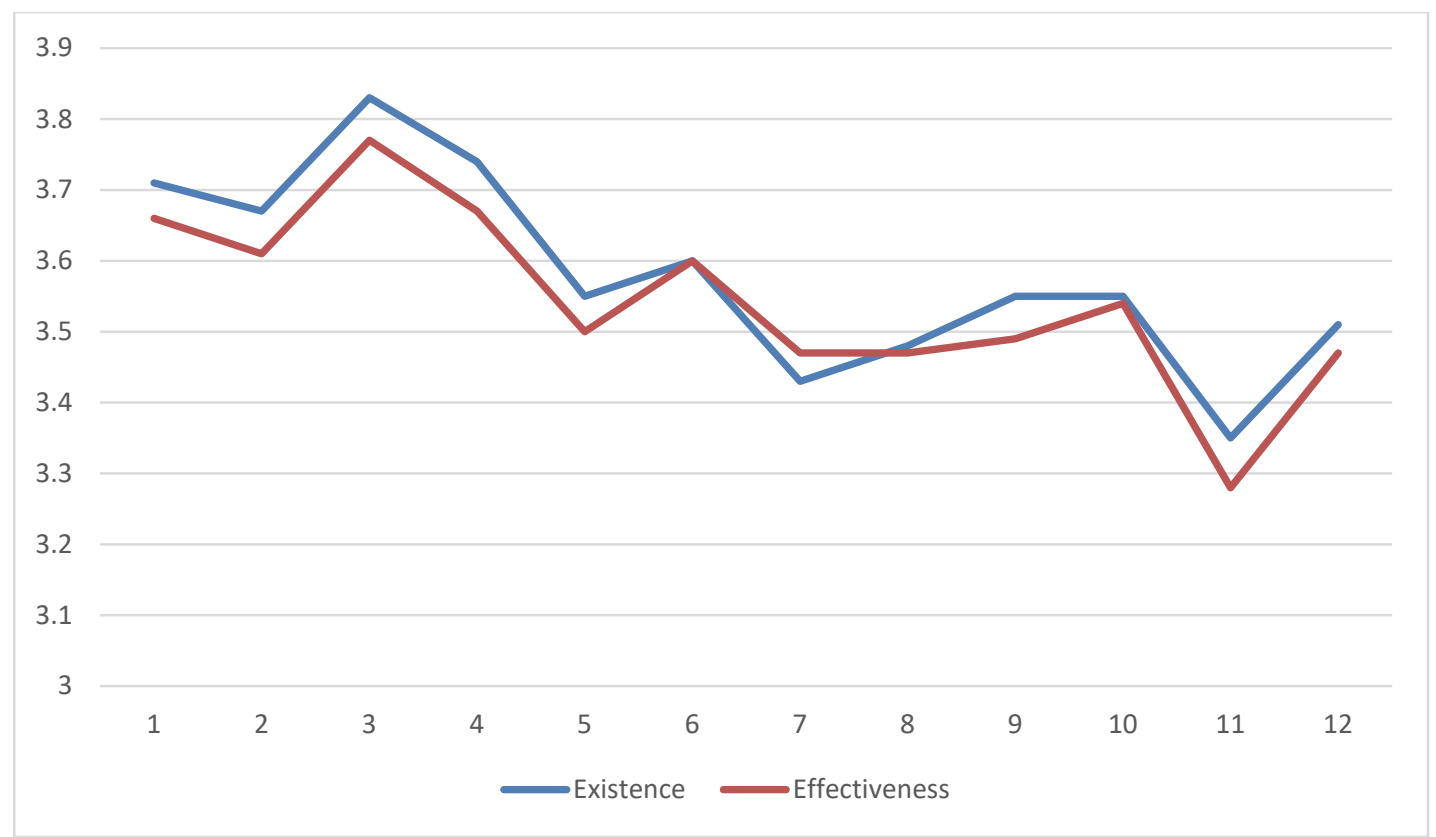

Fig. 2. Comparative analysis of the existence and effectiveness of village fund fraud prevention

For further analysis to determine whether the difference between a score of average total interest informant to the existence and effectiveness is significant or not performed paired t-test. Table 2 establishes the effect of paired sample tests, and the results do not establish a significant difference between the total average mean score and the total average effectiveness score $(\mathrm{t}=1.867, \mathrm{p}>0.05)$.

Table 2

Paired sample tests

\begin{tabular}{|c|c|c|c|c|c|c|c|}
\hline \multicolumn{8}{|c|}{ Paired Samples Statistics } \\
\hline & & Mean & Std. Deviation & Std. Error Mean & $\mathrm{t}$ & $\mathrm{df}$ & $\mathrm{P}(\mathrm{T}<=\mathrm{t})$ two tail \\
\hline \multirow[t]{2}{*}{ Part1 } & Existence & 3.452 & 0.321 & 0.024 & 1.867 & 178 & 0.064 \\
\hline & Effectiveness & 3.435 & 0.339 & 0.025 & & & \\
\hline
\end{tabular}

\subsection{Descriptive analysis of research variables}

The factors in this study are shown in Table 5 according to, standard deviations, reliability, estimates of interrelationships. Cronbach's alpha score for all constructs exceeds the recommended score of 0.70 (Nunnally, 1978), which means that all indicators load very high on each construct. Spearman's Rank Order Correlation (rho) is used to analyze the strength of relationships between variables. The results of this research paper show that there is a correlation to acquisitive moderate between habitual honesty and effective fraud prevention mechanism ( rho $=0.398$; $\mathrm{p}<0.05$ ), which means the habit of honesty associated with the mechanism of effective fraud prevention. Also, the results showed that there was an insignificant positive correlation between internal control processes and effective fraud prevention mechanisms $(r h o=0.220 ; p>0.05)$. This shows that the internal control process is less effective in preventing fraud. Also, the results indicate that there is a weak positive correlation between the supervisory function and the effective fraud prevention mechanism ( $r h o=0.014 ; p>0.05$ ). This shows that developing a good oversight function does not necessarily lead to a better level of effective fraud prevention mechanisms.

Table 3

The results of correlation matrix

\begin{tabular}{|c|c|c|c|c|c|c|c|c|c|c|c|c|}
\hline & mean & sd & $\mathrm{Ca}$ & 1 & 2 & 3 & 4 & 5 & 6 & 7 & 8 & 9 \\
\hline BK_Existence & 37151 & 0.45264 & 0.870 & 1 & & & & & & & & \\
\hline CL_Existence & 34860 & 0.51229 & 0.793 & $0.489^{* *}$ & 1 & & & & & & & \\
\hline PPS Existence & 35028 & 0.58420 & 0.843 & $0.553^{* *}$ & $0.585^{* *}$ & 1 & & & & & & \\
\hline PR_Existence & 34358 & 0.50842 & 0.903 & $0.393^{* *}$ & $0.413^{* *}$ & $0.295^{* *}$ & 1 & & & & & \\
\hline BK_Effectiveness & 36592 & 0.47530 & 0.894 & $0.800^{* *}$ & $0.487^{* *}$ & $0.543^{* *}$ & $0.430^{* *}$ & 1 & & & & \\
\hline CL_Effectiveness & 34972 & 0.52332 & 0.840 & $0.490^{* *}$ & $0.586^{* *}$ & $0.641^{* *}$ & $0.429^{* * *}$ & $0.561^{* *}$ & 1 & & & \\
\hline PPS Effectiveness & 34693 & 0.59294 & 0.821 & $0.536^{* *}$ & $0.604^{* *}$ & $0.867^{* *}$ & $0.374^{* *}$ & $0.641^{* *}$ & $0.713^{* *}$ & 1 & & \\
\hline PR_Effectiveness & 34302 & 0.51863 & 0.918 & $0.375^{* *}$ & $0.371^{* *}$ & $0.246^{* *}$ & $0.864^{* *}$ & $0.389^{* *}$ & $0.338^{* *}$ & $0.346^{* *}$ & 1 & \\
\hline Fraud_Prevention & 37542 & 0.44460 & 0.868 & $0.487^{* *}$ & $0.403^{* *}$ & $0.420^{* *}$ & $0.376^{* *}$ & $0.535^{\text {** }}$ & $0.535^{* *}$ & $0.469^{* *}$ & $0.336^{\text {** }}$ & 1 \\
\hline
\end{tabular}

**. Correlation is significant at the 0.01 level (2-tailed). 


\subsection{Hypothesis Testing}

Multiple regression is used to prove the hypothesis developed in this study. Because all correlations developed in this study have positive and negative correlations, a two-sided test for the t distribution is applied. According Hair et al. (2016), the critical $t$ score for the two-tailed test was $2.293(p<0.05), 0.339(p>0.05), 1.194(p>0.05) 0.570(p>0.05) 0.073(p>0.05)$ $0.468(p>0.05) 0.469(p>0.05)$ and $0.168(p>0.05)$. Observing deeply on ANOVA tests (Table 6) determined that the overall model was significant $(\mathrm{f}=15.08, \mathrm{p}<0.05)$.

Table 4

A two-sided test

\begin{tabular}{lccccc}
\hline & Sum of Squares & df & Mean Square & F & Sig. \\
\hline Regression & 12.209 & 8 & 1.526 & 11.292 & 0.000 \\
Residual & 22.975 & 170 & 0.135 & & \\
\hline Total & 35.184 & 178 & & & \\
\hline
\end{tabular}

Table 5 determines that the inflation fact or (VIF) variance score is less than 5 and the tolerance score is greater than 0.2 . This determined that multicollinearity was not a problem in this study (Hair et al, 2016). In addition, Table 5 stipulates that BK_Existence $(\mathrm{B}=0.098(\mathrm{P}>0.05)$ CI_Existence $(\mathrm{B}=-0.012(\mathrm{P}>0.05)$ PPS_Existence $(\mathrm{B}=0.078(\mathrm{P}>0.05) \mathrm{PR} E$ E consistency $(\mathrm{B}$ $=0.041(\mathrm{P}>0.05)$ Effectiveness $(\mathrm{B}=0.254(\mathrm{P}<0.05)$ Effectiveness $(\mathrm{B}=0.144(\mathrm{P}>0.05)$ Effectiveness $\mathrm{PPS}(\mathrm{B}=-0.026(\mathrm{P}>$ $0.05)$ Effectiveness $(\mathrm{B}=0.088 \mathrm{P}>0.05)$ has a positive and significant strength in effective fraud prevention and explains 45.9 percent of the variance $\left(\mathrm{R}^{2}\right)$.

Table 5

Result of Hypothesis Testing

\begin{tabular}{lcccccc}
\hline Hypothesis & Path coefficient & t-value & R-Square & Tolerance & VIF & Decision \\
\hline $\mathrm{H}_{1}$ & 0.271 & 2.267 & 0.459 & 0.268 & 3.726 & Supported \\
$\mathrm{H}_{2}$ & 0.17 & 1.241 & & 0.205 & 4.873 & Not Supported \\
$\mathrm{H}_{3}$ & -0.035 & -0.23 & & 0.168 & 5.946 & Not Supported \\
$\mathrm{H}_{4}$ & 0.103 & 0.829 & & 0.251 & 3.987 & Not Supported \\
\hline
\end{tabular}

\section{Discussion}

This review is interesting that honesty habits have a positive relationship with the effective mechanism of fraud prevention of village funds. So, this finding supports previous research on the correlation between honesty culture and effective fraud prevention mechanisms consistent with the arguments of (Sengur, 2012), (Murphy \& Dacin, 2011), (CIMA, 2009), ((AICPA), 2002) and (IUCN, 2008) which claim to establish honesty habits is the main thing in preventing corporate fraud. Besides, this was also in agreement with Hernandez and (Hernandez \& Groot, 2007, p. 36) found that reducing control over management attitudes is more important than incentives and opportunities for fraud, in identifying fraud risks. There is a strong link between internal control and effective fraud prevention, which finds strong internal controls difficult for fraudsters to commit fraud by increasing the likelihood that fraudsters will be caught. (Shanmugam et al., 2012) show that no matter the size and type of organization, effective internal control measures are needed to prevent fraud, detect fraud and produce accurate financial reports. Likewise, (Hernandez \& Groot, 2007) found that strong internal controls are very important for fraud prevention. Findings of the correlation between developing an appropriate supervisory role and effective fraud prevention are also consistent with previous research [see American Institute of ((AICPA), 2002), (IUCN, 2008) which argues that an effective fraud prevention process requires an appropriate oversight function. Indeed, without the proper oversight function, the developed internal controls will not be implemented properly, or some employees will try to override the existing controls.

Findings of the correlation between developing and building attitudes of religious behavior and effective fraud prevention in village fund management are also following previous research according to (Neff, 2006) needed religious tactics and spiritual dimensions that are valid and appropriate for diverse ethnic groups in fraud prevention mechanisms. The latest findings in this study provide strong support that an effective fraud prevention mechanism must be carried out jointly to benefit highly from the fraud prevention mechanism from honesty habits, good internal control, the development of appropriate supervision, and the application of religious behavior. And vice versa will be less effective if done partially. This inquiry opened our eyes that all the informants have the same perception of the important role of the existence of precaution fraud effectively as an instrument of potential that can increase the competitive ability of institutions, improve profitability, organizational governance villages so that it makes it not susceptible to fraud, financial losses and improve reputation and image. However, a close look at Figure-t-test showed that the gap was not significant between the presence and effectiveness of fraud prevention measures. This situation is considered to be the limited ability of village fund management to support the implementation of strong fraud prevention tactics, which causes these institutions to use little or no effective fraud prevention mechanisms. More clearly, the results of this study found that most small institutions such as villages focused on low-cost methods to avoid fraud, 
such as building a positive workplace environment, consistent in responding to reported fraud cases, and having a code of ethics and improving facilities religiously. From another point of view, more effective and efficient ways that can reduce the incidence of fraud are avoided because of high costs. The method can include an internal unit to deal with fraud issues, including external auditors and conduct training programs to increase employee awareness of fraud-related issues and build facilities within the village organization to increase the religious activities of the village institution.

\section{Conclusion}

The review was done to see the score level where tactics Flood protection fraud at the institution level as a village in Indonesia. Besides, this study Beru marsh tactics advocated effective fraud at the institution's smallest one level in the village. Furthermore, the review revealed that agencies village level had been run some deterrence tactics deception to minimize fraudulent activities that threaten the sustainability of the institution they are. Building a positive workplace and everyday attitudes to religious behavior, such as that I believe in God who oversees me is found as a method of counteracting fraud that is most applied by village-level institutions in Indonesia. Meanwhile, creating an internal audit, bringing in a third party, such as a certified external auditor and fraud awareness training is a tactic that is not often implemented. In matters of effectiveness, finding consistent responses to reported fraud cases, building a positive workplace environment, creating an internal audit unit, internal control, and increasing management's attention to fraud risks and building religious attitudes are considered the most effective measures. When the fraud prevention tactics listed are grouped into the dimensions of honesty, internal control processes, appropriate supervisory functions, building religious attitudes, the results of this study show that these four dimensions contribute to effective and unique fraud prevention. Overall, this review has revealed fraud prevention tactics that can be applied by village institutions in Indonesia and other villages in developing countries to reduce the risk of fraud. This study concludes that for village institutions in Indonesia to eliminate fraud, they should consider investing resources in implementing effective and efficient fraud prevention tactics, especially in establishing religious behavior, establishing honesty and high integrity, carrying out programs training, and involving a certified external auditor. By (Bierstaker et al., 2006), small institutions are more reluctant to invest their resources in fraud prevention. Besides, because this study does not specify a particular institution, further investigation can be done by looking at fraud prevention tactics that are more specific for the business sector or certain larger institutions. Also, future studies can broaden the scope of informants to cover large categories and/or many villages. A study similar can be done for the villages located on the island of Borneo, Sumatra, Sulawesi, Aceh or Papua and East Java, or even in another country. The findings of the study can then be compared with the results of this study.

On the other hand, the possible gap between perceptions and actual practices in village-level institutions in Indonesia can be considered negligence from the central government, which is negligent to implement policies, rules, regulations, and procedures as well as building religious attitudes to control and eliminate problems related to fraud. Besides, this gap in village institutions can also be caused by the lack of attention given by the central government and legislators to the problem of fraud in village institutions.

\section{References}

ACFE (2012), "Report to the nations on occupational fraud and abuse", available at: www.acfe.com/ uploadedFiles/ACFE_Website/Content/rttn/2012-report-to-nations.pdf (accessed 24 January 2014)

(AICPA), A. I. of C. P. A. (2002). Due Profesional Care in The Performance Of Work. Statement Auditing Standart No. 230. New York, NY:AICPA.

Adams, G. W., Campbell, D. R., Campbell, M., \& Rose, M. P. (2006). Fraud prevention. The CPA Journal, $76(1), 56$.

Ashbaugh-Skaife, H., Collins, D. W., Kinney Jr, W. R., \& LaFond, R. (2008). The effect of SOX internal control deficiencies and their remediation on accrual quality. The Accounting Review, 83(1), 217-250.

Barra, R. A. (2010). The impact of internal controls and penalties on fraud. Journal of Information Systems, 24(1), 1-21.

Berger, L., Perreault, S., Wainberg, J., Courtois, C., Gendron, Y., Donelson, D. C., Ege, M. S., McInnis, J. M., \& Fan, Y. (2017). Auditing: A Journal of Practice \& Theory A Publication of the Auditing Section of the American Accounting Association.

Bierstaker, J. L., Brody, R. G., \& Pacini, C. (2006). Accountants' perceptions regarding fraud detection and prevention methods. Managerial Auditing Journal, 21(5).

Bishop, T. J. F. (2004). Preventing, deterring, and detecting fraud: What works and what doesn't. Journal of Investment Compliance, 5(2).

Button, M., Gee, J., \& Brooks, G. (2012). Measuring the cost of fraud: an opportunity for the new competitive advantage. Journal of Financial Crime, 19(1).

Carpenter, B. W., \& Mahoney, D. P. (2001). Analyzing organizational fraud. Internal Auditor, $58(2), 33$.

CIMA. (2009). Fraud risk management: a guide to good practice. www.cimaglobal.com/documents/importeddocuments/cid_techguide_fraud_risk_management_feb09.pdf.pdf101

Conroy, S. J., \& Emerson, T. L. N. (2004). Business ethics and religion: Religiosity as a predictor of ethical awareness among students. Journal of Business Ethics, 50(4), 383-396. 
Daigle, R. J., Hayes, D. C., \& Morris, P. W. (2014). Dr. Phil and Montel help AIS students "get real" with the fraud triangle. Journal of Accounting Education, 32(2), 146-159.

Deng, Y., Morck, R., Wu, J., \& Yeung, B. (2015). China's pseudo-monetary policy. Review of Finance, 19(1), 55-93.

Doig, A. (2014). Roadworks ahead? Addressing fraud, corruption and conflict of interest in English local government. Local Government Studies, 40(5), 670-686.

Donelson, D. C., Ege, M. S., \& McInnis, J. M. (2017). Internal control weaknesses and financial reporting fraud. Auditing: A Journal of Practice \& Theory, 36(3), 45-69.

Girgenti, R. H., \& Hedley, T. P. (2011). Managing the risk of fraud and misconduct: meeting the challenges of a global, regulated and digital environment. McGraw Hill Professional.

Glock, C. Y., \& Stark, R. (1970). Religion and society in tension: a publi. from the research program in the Sociology of Religion Survey Research Center, Univ. of Calif., Berkeley.

Hair, J., Celsi, M., Money, A., Samouel, P. and Page, M. (2016). Essentials of Business Research Methods, 3rd ed. Routledge/Taylor \& Francis.

Halbouni, S. S., Obeid, N., \& Garbou, A. (2016). Corporate governance and information technology in fraud prevention and detection. Managerial Auditing Journal, 31(6/7), 589-628.

Hernandez, J. R., \& Groot, T. L. C. M. (2007). Corporate fraud: Preventive controls which lower fraud risk. ARCA, Amsterdam Research Center in Accounting.

Hollow, M. (2014). Rogue Banking: a history of financial fraud in interwar Britain. Springer.

IUCN. (2008). The IUCN anti-fraud policy. http://cmsdata.iucn.org/downloads/anti_fraud_policy.pdf

Kapardis, M. K., \& Papastergiou, K. (2016). Fraud victimization in Greece: room for improvement in prevention and detection. Journal of Financial Crime, 23(2).

KPMG. (2013). KPMG Forensic-Survey of fraud, bribery and corruption in Australia and New Zealand 2012.

Kummer, T.-F., Singh, K., \& Best, P. (2015). The effectiveness of fraud detection instruments in not-for-profit organizations. Managerial Auditing Journal.

Laufer, D. (2011). Small business entrepreneurs: A focus on fraud risk and prevention. American Journal of Economics and Business Administration, 3(2), 401-404.

Mihret, D. G. (2014). How can we explain internal auditing? The inadequacy of agency theory and a labor process alternative. Critical Perspectives on Accounting, 25(8), 771-782.

Murphy, P. R., \& Dacin, M. T. (2011). Psychological pathways to fraud: Understanding and preventing fraud in organizations. Journal of Business Ethics, 101(4), 601-618.

Neff, J. A. (2006). Exploring the dimensionality of "religiosity" and "spirituality" in the Fetzer multidimensional measure. Journal for the Scientific Study of Religion, 45(3), 449-459.

Omar, N., \& Abu Bakar, K. M. (2012). Fraud prevention mechanisms of Malaysian government-linked companies: An assessment of existence and effectiveness. Journal of Modern Accounting and Auditing, 8(1), 15-31.

Perri, F. S., \& Brody, R. G. (2012). The optics of fraud: Affiliations that enhance offender credibility. Journal of Financial Crime, 19(3).

Peterson, B. K., \& Zikmund, P. E. (2004). 10 truths you need to know about fraud. Strategic Finance, 29-35.

Pong, C., Fraser, I., Barlaup, K., Drønen, H. I., \& Stuart, I. (2009). Restoring trust in auditing: Ethical discernment and the Adelphia scandal. Managerial Auditing Journal, 24(2).

RATLEY, J. (n.d.). Report to the Nations: On occupational fraud and abuse. 2012. Access in Http://Www. Acfe. Com/UploadedFiles/ACFE_Website/Content/Rttn/2012-Report-to-Nations. Pdf.

Seetharaman, A., Low, K. L. T., \& Saravanan, A. S. (2004). Comparative justification on intellectual capital. Journal of Intellectual Capital, 5(4).

Sengur, E. D. (2012). AUDITORS'PERCEPTION OF FRAUD PREVENTION MEASURES: EVIDENCE FROM TURKEY. Annales Universitatis Apulensis-Series Oeconomica, 14(1).

Shanmugam, J. K., Ali, A., Hassan, M., \& Haat, C. (2012). Internal control, risk management and fraud prevention measures on SMEs: reliability and validity of research instrument. Small, 100, 12-18.

Sow, A. N., Basiruddin, R., Mohammad, J., \& Rasid, S. Z. A. (2018). Fraud prevention in Malaysian small and medium enterprises (SMEs). Journal of Financial Crime

Umar, H. (2013). Metode Penelitian untuk Skripsi dan Tesis Bisnis Edisi Kedua. Rajawali Pers.

Wells, J. T. (2004). New approaches to fraud deterrence. JOURNAL OF ACCOUNTANCY-NEW YORK-, 197(2), 72-76.

Wolfe, D. T., \& Hermanson, D. R. (2004). The fraud diamond: Considering the four elements of fraud. 
(C) 2021 by the authors; licensee Growing Science, Canada. This is an open access article distributed under the terms and conditions of the Creative Commons Attribution (CC-BY) license (http://creativecommons.org/licenses/by/4.0/). 